\title{
Sleep quality in the elderly with and without chronic pain
}

\author{
Qualidade do sono em idosos com e sem dor crônica
}

Fatima Ferretti ${ }^{1}$, Daiana Teodoro dos Santos ${ }^{2}$, Leticia Giuriatti ${ }^{2}$, Ana Paula Maihack Gauer ${ }^{3}$, Carla Rosane Paz Arruda Teo ${ }^{1}$

DOI 10.5935/2595-0118.20180027

\section{ABSTRACT}

BACKGROUND AND OBJECTIVES: Brazil has been experiencing rapid aging of its population. Aging, even without chronic diseases, involves some functional loss, which is expressed by reduction in vigor, strength, readiness, metabolic efficiency, and often pain, which can lead to fatigue and sleep changes. Sleep quality is essential for the physical and emotional well-being of elderly individuals. The objective of this study was to evaluate the sleep quality among elderly with and without chronic pain that live in a town in Santa Catarina State.

METHODS: Interviews with 385 senior citizens living in the urban area of a town in Santa Catarina. The research tools used in the data collection were the Mini-Mental State Examination, an instrument adapted from Morais, the visual numerical scale and the Pittsburgh questionnaire.

RESULTS: Among the elderly interviewed, females (67.27\%, $\mathrm{n}=259)$ and the 60-69 years age group $(45.45 \%, \mathrm{n}=175)$ prevailed. Among the 385 elderlies, 58.18\% $(n=224)$ had chronic pain, predominantly of moderate intensity $(48.66 \%, \mathrm{n}=109)$. Among the elderly with pain, $57.59 \%(n=129)$ presented poor sleep quality; among those without pain, 56.52\% ( $n=91)$ had good sleep quality.

CONCLUSION: It is concluded that the intensity of pain, number of chronic self-reported diseases and age group are factors that influence the sleep quality of the elderly, thus indicating the importance of health professionals working in this context with new studies and resources.

Keywords: Diseases, Elderly health, Physiotherapy, Sleep disorders.

1. Universidade Comunitária da Regiẫo de Chapecó, Programa de Pós-Graduação Stricto Sensu em Ciências da Saúde, Chapecó, SC, Brasil.

2. Universidade Comunitária da Regiāo de Chapecó, Chapecó, SC, Brasil.

3. Universidade do Oeste de Santa Catarina, Curso de Fisioterapia, Joaçaba, SC, Brasil.

Submitted in January 09, 2018.

Accepted for publication in March 19, 2018.

Conflict of interests: none - Sponsoring sources: none.

Correspondence to

Av. Senador Atílio Fontana, 591-E - Efapi

89809-000 Chapecó, SC, Brasil.

E-mail: ferrettifisio@yahoo.com.br

(C) Sociedade Brasileira para o Estudo da Dor

\section{RESUMO}

JUSTIFICATIVA E OBJETIVOS: O Brasil vivencia o rápido envelhecimento da sua população. Envelhecer, ainda que sem doenças crônicas, envolve alguma perda funcional, que é expressa por diminuição de vigor, força, prontidão, eficiência metabólica e, muitas vezes, dores, que podem acarretar fadiga e alteraçóes na qualidade do sono, aspecto essencial para o bem-estar físico e emocional de indivíduos idosos. O objetivo deste estudo foi avaliar a qualidade do sono em idosos, com e sem dores crônicas, que residem em um município catarinense.

MÉTODOS: Foram entrevistados 385 idosos residentes no ambiente urbano de um município catarinense. Os instrumentos utilizados na coleta de dados foram o mini-exame de estado mental, instrumento adaptado de Morais, escala visual numérica e o questionário de Pittsburgh.

RESULTADOS: Dentre os idosos entrevistados, prevaleceram o sexo feminino $(67,27 \% ; n=259)$ e a faixa etária de 60 a 69 anos $(45,45 \% ; n=175)$. Dos 385 idosos, 58,18\% ( $n=224)$ possuem dor crônica, predominantemente de intensidade moderada $(48,66 \% ; n=109)$. Entre os idosos com dor, 57,59\% ( $n=129)$ apresentaram qualidade do sono ruim; entre os sem dor, $56,52 \%$ $(\mathrm{n}=91)$ tiveram qualidade do sono boa.

CONCLUSÁO: A intensidade da dor, quantidade de doenças crônicas autorrelatadas e faixa etária são fatores que influenciam na qualidade do sono de idosos, indicando a importância de os profissionais da saúde atuarem nesse contexto com novos estudos e recursos.

Descritores: Doenças, Fisioterapia, Saúde do idoso, Transtornos do sono.

\section{INTRODUCTION}

Brazil has been experiencing rapid aging of its population. The fall of mortality and fertility rates in a short period has fostered the transition of a young population to an older population ${ }^{1}$. Currently, approximately $11 \%$ of the Brazilian population is formed by old people, and it is estimated that this number will triple by $2050^{2}$. Veras ${ }^{3}$ highlights that "aging, even without chronic diseases, involves some functional loss that is expressed by a reduction in vigor, strength, readiness, the speed of systemic reaction and metabolic efficiency". Changes in the quality of sleep are among the changes that can happen to the subject in this phase of the life. The aging process generates changes in sleep, both quantitative and qualitative, reducing the sleeping capacity that can be associated with comorbidities and not only with age itself ${ }^{4}$.

Sleeping is essential for the physical and emotional well-being. Poor sleep may cause falls, cognitive decline and nega- 
tively impact life and health conditions of elderly individuals, as well as boost other disorders intensifying painful pictures, for example. Complementing, among the diseases that affect the elderly, pain appears as one the most common complaints since it directly impacts daily activities and mobility. Among the types of pain, the chronic pain is predominant - the one that persists for more than three months and is manifested in a continuous or recurrent way 5 .

Studies show different percentages of chronic pain among the elderly, and it can vary from 29.3 to $51.4 \%{ }^{6-8}$. However, any pain can cause fatigue, anorexia, sleep changes, constipation, nausea, and difficulty of concentration, generating suffering? The individuals that have some type of pain can be impacted by changes in the independence to perform their daily activities and the capacity to enjoy life ${ }^{10}$. One should remember that the sleep pattern of old people can be modified by painful pictures ${ }^{11}$, which emphasizes the need to analyze the sleep quality of the elderly with and without chronic pain. From this information, one can produce innovative strategies to minimize the suffering produced by pain and provide health professionals with instruments to plan interventions to prevent these situations aiming at decreasing its indexes and improving the quality of sleep.

Given this context, this study aimed to evaluate the sleep quality in the elderly with and without chronic pain, living in a city of the Santa Catarina State.

\section{METHODS}

This is a quantitative, cross-sectional and populational study, conducted in a city of the State of Santa Catarina, from June to August 2016. This study included old people of both genders, living in the urban area of the city.

The State of Santa Catarina has a dynamic that it is reflected in high growth, literacy, job and per capita income rates, significantly superior to the national averages, ensuring a better quality of life for the population, but with contrasts regarding the socioeconomic development of its cities. The economy of the city hosting the research is strongly linked to agriculture, agribusiness and metal-mechanics industries and small companies. The city has a diversified culture influenced by the Italian and German colonization, mingled with the local characteristics. Many of the colonizers' descendants have established their lives in the city and make up the young, the adult and, mainly, the elderly population of this city ${ }^{12}$.

\section{Population/sample by conglomerates}

For the sample size calculation, we considered a population of 13.606 old residents in the city ${ }^{13}$, of both the genders, with 60 years or more. The sample of the study was calculated by Microsoft Excel', considering a confidence interval of 95\% and margin of error of $5 \%$, totalizing 385 old subjects. The criteria inclusion were to be 60 years old or more, to live in the urban area of the studied city and to have good cognition, according to the Mini-Mental State Examination (MMSE), as the degree of schooling established by the test score. The exclusion criteria were the old subject absent from home in two visits; be bedridden or wheelchaired.

Data collection was organized from the city census map, which has 38 sectors. Ten census sectors were randomly drawn. The maps of these sectors were printed so that the researchers could plan the collection according to the streets of each quarter. At every two houses, the first was selected. When the selected place was a building, all people above 60 years were interviewed. Commercial lots and establishments were excluded and, when drafted, the next domicile was used - successively, in all the streets until reaching the sample.

\section{Data collection instruments}

Data collection instruments used were the adapted Morais questionnaire $^{14}$ to identify personal data and if the old subject had chronic pain or not. And then, the visual numeric scale (VNS) to measure his/her pain intensity. This scale is divided into 11 equal parts, from zero the 10 , where the subject classifies its pain according to the following parameters: from zero to three corresponding to "mild pain"; from four to seven, to "moderate pain"; above eight, to "severe pain"15.

Finally, the Pittsburgh questionnaire was applied to evaluate the quality of sleep. This instrument has 19 questions, grouped in seven components, with weight distributed in a zero-tothree scale ${ }^{16}$. The scores of these components are added up to produce one global score that varies from zero to 21 . Scores from zero to four indicate a good sleep quality; from five to ten indicate bad quality, and above 10 indicate sleep disorder ${ }^{17}$.

\section{Data collection procedures}

Fourteen students were previously trained to use the data collection instruments - two master's degree students, one student of the Medical School graduation course, 11 students of the Physiotherapy graduation course - all members of the study research group. The training duration was of 20 hours. Five hours dedicated to studying the instruments; five for a pilot with 15 elderly subjects to check the adequacy of the data collection instruments; five to check the results of the pilot test and necessary adjustments to start the official data collection of the study, and five to organize the data collection dynamics.

The collection was carried out in the 10 selected census sectors. Each interviewer registered the data on the map previously received. The research team met every Friday to input the data in the database and assess the course of the collection, check the covered streets and plan for the following week. Data collection was in the morning, afternoon and evening, in all days of the week, from June to August 2016. When, in the drafted house there was an old subject, but he/she was not in at the moment of the visit, the researcher came back on a different date according to the availability suggested by the person who was in the house.

Each old subject found in the house was informed about the purpose of the research, its relevance, objectives, methods, expected benefits, potential risks, and nuisance, as well as about the form as the data would be collected and used later. Those 
that accepted to participate signed the Free and Informed Consent Form (FICT).

Following, the MMSE was applied, used as an inclusion criterion since it screens the cognitive preservation of the elderly. Its interpretation was based on the following scores: 17 points for illiterates or less than four years of schooling, 24 points for individuals with four years of schooling or more ${ }^{18}$. The elderly who reached these cut-off points remained in the study, and the others were excluded for not having a good cognition. Then, the Morais adapted general data questionnaire for the elderly was applied. This instrument comprises personal information and questions related to the presence of pain and the number of self-reported chronic diseases ${ }^{14}$. The age was grouped by age range into 60-69; 70-79 and more than 80 years of age. Gender in female and male. The number of chronic diseases was selfreported and classified in none, up to 3 and above 4. After that, the VNS was applied. It is a scale that goes from zero to 10 and helps in assessing the patient's pain intensity. The old subject classified its pain by intensity, from zero to three corresponding to "mild pain," four to seven, "moderate pain," and above of eight corresponding to "severe pain ${ }^{15}$. Finally, the Pittsburgh scale (PSQI), developed with the objective to evaluate the quality of sleep in relation to the most recent month. This questionnaire has 19 questions grouped into seven components, with weight distributed on a zero-to-three scale. The scores of these components are added up to produce the global score ${ }^{19}$.

\section{Ethical aspects}

The project originated this study was evaluated and approved by the Ethics Committee of Research with Humans of the Institution under number CAE 613611160.0000.0116. This study followed the ethical principles of the Resolution 466/12 of the National Health Council.

\section{Statistical analysis}

Initially, the data were analyzed by descriptive statistics and also categorized and analyzed by the SPSS software, version 20.0. First, descriptive statistics with average and the standard deviation was used, and the frequency distribution of the variables quality of sleep, pain intensity, age and number of self-reported chronic diseases. The level of significance was determined a priori as $\mathrm{p} \leq 0.05$, using the Chi-square test. For the inferential analysis, the Kolmogorov-Smirnov test was conducted. The Spearman correlation test was used to compare the average of the results between the sleep quality scores in both groups (with and without chronic pain).

\section{RESULTS}

In the sample of the present study, females prevailed with $67,3 \%(n=259)$. Concerning the age, the 60 to 69 age group predominated, accounting for $45.5 \%(\mathrm{n}=175)$ of the sample. Regarding the presence of chronic pain, 58.18\% ( $\mathrm{n}=224)$ reported this symptom. In terms of the number of self-reported chronic diseases, up to three was the most common, in $79.0 \%$ $(n=304)$. Concerning the intensity of pain, it was observed that $58.18 \%(\mathrm{n}=224)$ had reported some pain. Of these, $17.86 \%(\mathrm{n}=40)$ had mild pain; 48.66\% ( $\mathrm{n}=109)$, moderate pain; $33.48 \%(n=75)$, severe pain.

Table 1. Profile of the elderly sample, 2017

\begin{tabular}{lcc}
\hline Variables & Classification & $\mathrm{n}(385)(\%)$ \\
\hline Age (years) & $60-69$ & $175(45.45)$ \\
& $70-79$ & $154(40.00)$ \\
Gender & More than 80 & $56(14.55)$ \\
& Male & $126(32.73)$ \\
NEA & Female & $259(67.27)$ \\
& None & $50(12.99)$ \\
& Up to 3 & $304(78.96)$ \\
Intensity of pain (VNS) & Above 4 & $31(8.05)$ \\
& Mild & $40(17.86)$ \\
& Moderate & $109(48.66)$ \\
& Severe & $75(33.48)$ \\
\hline
\end{tabular}

$\mathrm{n}$ = sample size; $\%$ = sample percentage; NEA = number of self-reported diseases; VNS = visual numeric scale.

Source: elaborated by the authors

In table 2, among the elderly with chronic pain, $57.59 \%$ $(\mathrm{n}=129)$ presented bad quality of sleep and $8.48 \%(\mathrm{n}=19)$ reported sleep disorder. Among the elderly who did not have chronic pain, $56.52 \%(\mathrm{n}=91)$ had a good quality of sleep and only $2.26 \%(\mathrm{n}=5)$ had a sleep disorder. The difference was statistically significant $(\mathrm{p}=0.000)$ among old subjects with and without chronic pain.

Table 2. Quality of sleep in the elderly with and without chronic pain, 2017

\begin{tabular}{lccc}
\hline Chronic pain & Sleep classification & $\mathrm{n}=224(58.18 \%)$ & $\mathrm{p}$ value \\
\hline Presence & Good quality & $76(33.93 \%)$ & $0.000^{\star}$ \\
& Bad quality & $129(57.59 \%)$ & \\
& Sleep disorder & $19(8.48 \%)$ & \\
& Sleep classification & $161(41.82 \%)$ & \\
Absence & Good quality & $91(56.52 \%)$ & \\
& Bad quality & $65(40.37 \%)$ & \\
& Sleep disorder & $5(2.26 \%)$ & \\
\hline
\end{tabular}

$\mathrm{n}=$ sample size $\%$ = sample percentage $; \mathrm{p}$ value $=$ Person Chi-square statistics; *Level of significance: $p<0.0$.

Source: elaborated by the authors

Table 3 shows the data concerning the prevalence of pain, quality of sleep and age group. Among the old subjects who had chronic pain, the quality of the bad sleep worsened with age: $47.92 \%$ of those between 60 and 69 years; $62.10 \%$ of those between 70 and 79 years; for $72.73 \%$ of those with 80 years or more. Among the old subjects without chronic pain, there was a predominance of the good quality of sleep, increasing with age: $50.63 \%$ of those between 60 and 69 years; $62.71 \%$ of those of 70 the 79 years; $60.87 \%$ of those with 80 years or more.

Figure 1 shows the positive correlations between the quality of sleep and the amount of self-reported diseases $(r=0.24$, $\mathrm{p}=0.000$ ), and also between the quality of sleep and the intensity of pain $(\mathrm{r}=0.33 \mathrm{p}=0.000)$. 
Table 3. Prevalence of pain, quality of sleep and age group, 2017

\begin{tabular}{|c|c|c|c|c|c|c|c|}
\hline \multirow{2}{*}{$\begin{array}{l}\text { Variables } \\
\text { Age group } \\
\text { (years) }\end{array}$} & \multicolumn{3}{|c|}{ Presence of chronic pain } & \multicolumn{4}{|c|}{ Absence of chronic pain } \\
\hline & $\begin{array}{c}60-69 \\
96(42.85 \%)\end{array}$ & $\begin{array}{c}70-79 \\
95(42.41 \%)\end{array}$ & $\begin{array}{c}+80 \\
33(14.73 \%)\end{array}$ & $\begin{array}{c}60-69 \\
79(49.06 \%)\end{array}$ & $\begin{array}{c}70-79 \\
59(36.64 \%)\end{array}$ & $\begin{array}{c}+80 \\
23(14.28)\end{array}$ & $p$-value \\
\hline QSB & 39 (40.63\%) & $29(30.53 \%)$ & $8(24.24 \%)$ & 40 (50.63\%) & $37(62.71 \%)$ & $14(60.87 \%)$ & 0,00 \\
\hline QSR & $46(47.92 \%)$ & 59 (62.10\%) & $24(72.73 \%)$ & 35 (44.30\%) & 22 (37.29\%) & $8(34.78 \%)$ & \\
\hline DS & $11(11.45 \%)$ & $7(7.37 \%)$ & $1(3.03 \%)$ & $4(5.06 \%)$ & 0 & $1(4.35 \%)$ & \\
\hline Total & 96 (100\%) & 95 (100\%) & $33(100 \%)$ & 79 (100\%) & 59 (100\%) & $23(100 \%)$ & 385 (100\%) \\
\hline
\end{tabular}

$\%$ = sample percentage; $p=$ Person Chi-square statistics; QSB = good quality of sleep; QSR = bad quality of sleep; DS = sleep disorder. *Level of significance: $\mathrm{p}<0.05$.

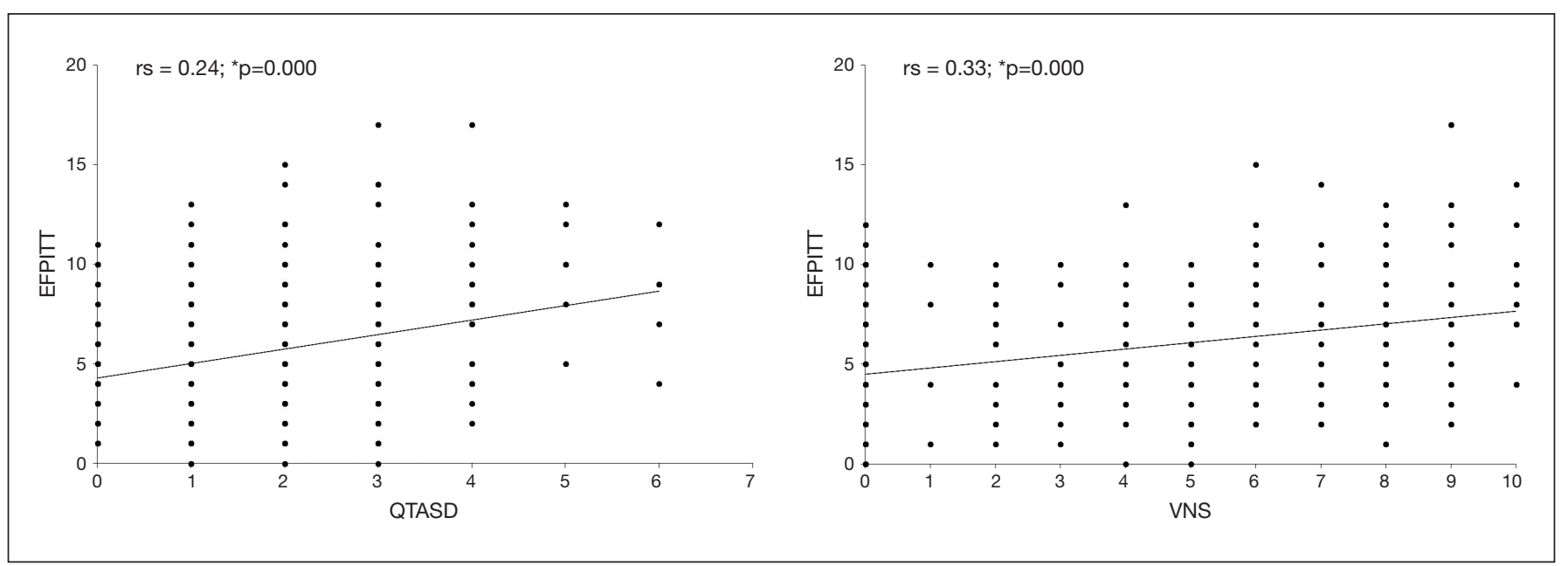

Figure 1. Correlation between the quality of the sleep and the number of chronic diseases and intensity of pain, 2017

EFPITT = Pittsburgh index; QTASD = amount of chronic diseases; VNS = visual numeric scale; rs = resulted. *Level of significance: $p<0.05$.

Source: Elaborated by the authors.

\section{DISCUSSION}

This study showed a higher number of women among the elderly - a prevalence of the female gender, an aspect already highlighted in the literature, given the feminization of aging ${ }^{20}$. Other studies also identified a higher number of women among the elderly in the community: $72.6,67.4$ and $70 \%{ }^{21-23}$.

The higher survival of old women is related with lesser exposure to the occupational risks, mortality rates due to external causes, tobacco and alcohol consumption and greater self-care in relation to the diseases and use of the health services ${ }^{24}$. Concerning the age, the 60 to 69 age group predominated, accounting for $45.5 \%(n=175)$. Data from the Brazilian Institute of Geography and Statistics (IBGE) for the concerned city have already highlighted this age group as predominant $(59.63 \%)^{13}$.

Concerning the presence and intensity of pain in aged, it is observed that $58.18 \%$ have chronic pain (Table 2); and the moderate intensity of pain predominated (48.66\%) (Table 1). These results are similar to the study conducted with 872 old subjects, where $543(52.8 \%)$ reported chronic pain and the intensity of the predominant pain was also moderate $(25.9 \%)^{25}$, although in a lesser proportion than what was observed in this study.

Dellaroza et al. ${ }^{8}$ also identified in a study with 1,271 old subjects, the predominance of the moderate pain (45.8\%), and they associated pain with impairment in the activities of daily life. In many situations, the elderly are taken to believe that the situation of chronic pain is natural in aging and, because of this, they fail to mention this symptom, even when pain affects their mood and functional level, making it impossible to treat, and worsening their quality of life ${ }^{26}$. The clinical assessment should include the pain questionnaire since only with a good follow-up on its occurrence and intensity will allow healthcare professionals to plan actions to minimize this picture.

The main result of this study shows that the majority of the old people with pain have a bad quality of sleep (57.59\%). Among those without chronic pain, the majority has a good quality of sleep (56.52\%). Monteiro and Ceolim ${ }^{27}$ described in a study that pain is among the causing factors of sleep disorders $(33.1 \%)$. Although pain interferes with the quality of sleep of old individuals, and despite its higher occurrence in aging, it by itself is not the cause of sleep disorders that are usually associated with comorbidities and worse scores of quality of life in the elderly ${ }^{28}$. Among the old subjects who had chronic pain, the bad quality of sleep increased with age: $47.92 \%$ between 60 to 69 years; $62.10 \%$ between 70 to 79 years; $72.73 \%$ among those with 80 years or more. Among the old subjects without chronic pain, there was a predominance of the good quality of sleep: $50.63 \%$ between 60 to 69 years; $62.71 \%$ between 70 to 79 years; $60.87 \%$ with 80 years or more. 
Pain and physical discomfort in the elderly lead to changes in the sleep pattern, that mainly occurs in more than half of old people above 65 years and tend to evolve with age. As years go by, there may be an increase in the number of diseases that accelerates aging, as well as the gradual decline of the function of several organ systems $s^{4,29,30}$, all factors that worsen the quality of sleep and the life of old people.

A positive correlation was found between self-reported diseases and the quality of sleep. The higher the number of self-reported chronic diseases, the worse is the quality of sleep. The higher the score of the quality of sleep, the greater the intensity of pain. It is known that the higher the number of chronic diseases, higher will be the interactions of symptoms and drugs, which produces a cycle that can generate different types of physical and psychological suffering.

Among the chronic diseases that produce painful pictures, the most common is musculoskeletal pain. A study that tried to correlate musculoskeletal changes with pain in old people concluded that these diseases in the aged population are followed by pain discomfort. The authors also observed that for $46.9 \%$ of the elderly, the pain pictures are considered a reasonable discomfort and that chronic pain can interfere with their life and health, affecting the quality of sleep ${ }^{31}$.

Chronic pain causes changes in the quality of sleep, which is relevant to the elderly because in addition to be very frequent, it can cause damages to their daily activities and health ${ }^{32}$. When the sleep pattern of old people is interrupted by pain, it can reduce their motivation and willingness to participate in social and recreational activities, consequently harming the performance of daily activities creating dependence and lowering the well-being $^{11}$. The number of old people who suffer from the bad quality of sleep is high. Among the factors that can interfere with the quality of sleep, are age, gender, schooling self-perceived general health ${ }^{29}$.

Veras $^{33}$ observed that, in aging, the presence of more than one self-reported chronic disease is common, which characterizes an aging society nowadays. Corrêa and Ceolim ${ }^{34}$ highlight that chronic diseases have a relation with bad quality of sleep and state that the early identification of sleep disorders is important so that the healthcare professionals can intervene favorably in the evolution of the picture.

Healthcare professionals should intervene with actions to promote health that minimize or prevent the sleep-related disorders. Among the strategies, it is worth mentioning relaxation techniques, integrative and complementary practices, conversation, and therapy and support groups. There is also the therapeutic touch that benefits old subjects with chronic pain. It is effective in reducing pain and in improving the quality of sleep ${ }^{35}$.

\section{CONCLUSION}

The results of this study had allowed concluding that the intensity of pain, amount of self-reported chronic diseases and age group are factors that negatively influence the quality of sleep of old people. Moreover, the higher the age group with the presence of pain, the worse is their scores of quality of sleep.

\section{REFERENCES}

1. Ramos LR, Cendoroglo MS (Coords.). Guia de geriatria e gerontologia. In: Carvalhães-Neto NC. Envelhecimento bem-sucedido e envelhecimento com fragilidade. Barueri: Manole; 2011.

2. Brasil. Ministério da Saúde. Agência Nacional de Saúde Suplementar. Plano de cuidado para idosos na saúde suplementar. Brasília: ANSS; 2012.

3. Veras R. A urgente e imperiosa modificaçāo no cuidado à saúde da pessoa idosa. Rev Bras Geriatr Gerontol. 2015;18(1):5-6.

4. Quinhones MS, Gomes MM. Sono no envelhecimento normal e patológico: aspectos clínicos e fisiopatológicos. Rev Bras Neurol. 2011;47(1):31-42.

5. Barros N. Entendendo a dor. Porto Alegre: Artmed; 2014. 136p.

6. dos Santos FA, de Souza JB, Antes DL, d'Orsi E. [Prevalence of chronic pain and its Association with the sociodemographic situation and physical activity in leisure of elderly in Florianópolis, Santa Catarina: population-based study]. Rev Bras Epidemiol. 2015;18(1):234-47. English, Portuguese.

7. Dellaroza MS, Pimenta CA. Impacto da dor crônica nas atividades de vida diária de idosos da comunidade. Cienc Cuid Saude. 2012;11(Suppl):235-42.

8. Dellaroza MS, Pimenta CA, Duarte YA, Lebrăo ML. [Chronic pain among elderly residents in São Paulo, Brazil: prevalence, characteristics, and association with functional capacity and mobility (SABE Study)]. Cad Saude Publica. 2013;29(2):325-34. Portuguese.

9. Cunha LL, Mayrink WC. Influência da dor crônica na qualidade de vida dos idosos. Rev Dor. 2011;12(2):120-4.

10. Batista AG, Vasconcelos LA. Principais queixas dolorosas em pacientes que procuram clínica de Fisioterapia. Rev Dor. 2011;12(2):125-30.

11. Freire AL, Alves LF, Torres MV, Xavier CL, Gomes JA, Lopes KS, et al. Análise comparativa da qualidade do sono em idosas praticantes e nâo praticantes de atividade física na zona sul de Teresina (Piauí). Gest Saúde Brasília. 2014;7(3):3101-14.

12. Santa Catarina. Governo de Santa Catarina. Conheça SC. Florianópolis -SC. Disponível em http://www.sc.gov.br/conhecasc. Acesso: nov. 2016.

13. Instituto Brasileiro de Geografia e Estatística (IBGE). Síntese de indicadores sociais: uma análise das condiçôes de vida da populaçăo brasileira, 2010. Rio de Janeiro: IBGE, 2010. Disponível em: https://biblioteca.ibge.gov.br/visualizacao/livros/liv98965. pdf. Acesso em: mar. 2016.

14. Morais EP. Envelhecimento no meio rural: condiçốes de vida, saúde e apoio dos idosos mais velhos de Encruzilhada do Sul - RS [doutorado]. Ribeiráo Preto (SP): Escola de Enfermagem de Ribeirâo Preto/USP; 2007.

15. Ciena AP, Gatto R, Pacini VC, Picanço VV, Magno IM, Loth EA. Influência da intensidade da dor sobre as respostas nas escalas unidimensionais de mensuraçấo da dor em uma população de idosos e de adultos jovens. Semina: Ciências Biológicas e da Saúde. Londrina, 2008;29(2):201-12.

16. Bertolazi AN. Traduçáo, adaptaçáo cultural e validaçáo de dois instrumentos de avaliação do sono: Escala de Sonolência de Epworth e Índice de Qualidade de Sono de Pittsburgh [dissertação]. Porto Alegre: Universidade Federal do Rio Grande do Sul; 2008.

17. Fonseca DC, Galdino DA, Guimarăes LH, Alves DA. Avaliaçăo da qualidade do sono e sonolência excessiva diurna em mulheres idosas com incontinência urinária. Rev. Neurocienc. 2010;18(3):294-9.

18. Amaral JR, Jacob WF. Avaliaçấo global do idoso. Sấo Paulo: Atheneu; 2005

19. Passos GA, Tufik S, Santana MG, Poyares D, Mello MT. Tratamento não farmacológico para a insônia crônica. Rev Bras Psiquiatr. 2007;29(3):279-82.

20. dos Santos AA, Ceolim MF, Neri AL. [Sleep complaints among Brazilian senior citizens from municipalities with different human development indexes]. Rev Lat Am Enfermagem. 2012; 20(5):917-26. English, Portuguese, Spanish.

21. Lopes JM, Fernandes SG, Dantas FG. Associação da depressão com as características sociodemográficas, qualidade do sono e hábitos de vida em idosos do Nordeste brasileiro: estudo seccional de base populacional. Rev Bras Geriatr Gerontol. 2015;18(3):521-31.

22. Santos-Orlandi AA, Ceolim MF, Pavarini SC, Oliveira-Rossignolo SC, Pergola-Marconato AM, Neri AL. Fatores associados à duraçáo dos cochilos entre idosos comunitários: dados do estudo multicêntrico fibra. Texto Contexto Enferm. 2016;25(1):e1200014.

23. Pimenta FB, Pinho L, Silveira MF, Batelho AC. Fatores associados a doenças crônicas em idosos atendidos pela Estratégia de Saúde da Família. Ciênc Saúde Coletiva. 2015;20(8):2489-98.

24. Silva NK, Oliveira ML. Fatores que interferem no sono dos alunos idosos da Universidade da Maturidade (UMA), na cidade de Palmas (TO). Rev Kair Geront. 2015;18(1):129-50.

25. Pereira LV, de Vasconcelos PP, Souza LA, Pereira Gde A, Nakatani AY, Bachion MM. [Prevalence and intensity of chronic and self-perceived health among elderly people: a population-based sduty]. Rev Lat Am Enfermagem. 2014;22(4):662-9. English, Portuguese, Spanish.

26. Santos FC, Souza PM, Nogueira SA, Lorenzet IC, Barros BF, Dardin LP. Programa de autogerenciamento da dor crônica no idoso: estudo piloto. Rev Dor. 2011;12(3):209-14.

27. Monteiro NT, Ceolim MF. Qualidade do sono de idosos no domicílio e na hospitalização. Texto Contexto Enferm. 2014;23(2):356-64.

28. Pereira AA, Ceolim MF. Relação entre problemas do sono, desempenho funcional e ocorrência de quedas em idosos da comunidade. Rev Bras Geriat Gerontol. 2011;44(4):769-78. 
29. Oliveira BH, Yassuda MS, Cupertino AP, Neri AL. [Relations between sleep patterns, perceived health and socioeconomic Variables in a sample of community residente elders: PENSA Study)]. Cien Saude Colet. 2010;15(3):851-60. Portuguese.

30. Cardoso AF. Particularidades dos idosos: uma revisão sobre a fisiologia do envelhecimento. Rev Digital. 2009;13(130):1-1.

31. Meneses GS, Leorne RO, Gouveia GP. Correlação das alteraçốes osteomioarticulares e dor em idosos de Morrinho (CE). RBCEH. 2013;10(2):139-49.

32. Araújo CL, Ceolim MF. [Sleep quality of elders living in long-term care institutions].
Rev Esc Enferm USP. 2010;44(3):619-26. Portuguese.

33. Veras RP. Estratégias para o enfrentamento das doenças crônicas: um modelo em que todos ganham. Rev Bras Geriatr Gerontol. 2011;14(4):779-86.

34. Corrêa K, Ceolim MF. [Sleep quality in aged patients with peripheral vascular disease]. Rev Esc Enferm USP. 2008;42(1):12-8. Portuguese.

35. Marta IE, Baldan SS, Berton AF, Pavam M, da Silva MJ. [The effectiveness of therapeutic thouch on pain, depression and sleep in patients with chronic pain: clinical trial. Rev Esc Enferm USP. 2010;44(4):1100-6. Portuguese. 